\title{
Melt features in ice cores from Site J, southern Greenland: some implications for summer climate since AD 1550
}

\author{
T. KAMEDA, \\ Kitami Institute of Technology, Koencho 165, Kitami, Hokkaido 090, Japan \\ H. NARITA, \\ Institute of Low Temperature Science, Hokkaido University, Sapporo, Hokkaido 060, Japan \\ H. SHOJI, \\ Kitami Institute of Technology, Koencho 165, Kitami, Hokkaido 090, Japan \\ F. Nishio, \\ Hokkaido University of Education, Shiroyama 1-15-55, Kushiro, Hokkaido 085, Japan \\ Y. Fujil and O. Watanabe \\ National Institute of Polar Research, Itabashi-ku, Tokyo 173, Japan
}

\begin{abstract}
Horizontal and vertical distributions of melt features (ice lavers) were examined using two ice cores $(206.6$ and $101.5 \mathrm{~m}$ deep, $1 \mathrm{~m}$ apart) from Site J $\left(66^{\circ} 51.9^{\prime} \mathrm{N}, 46^{\circ} 15.9^{\prime} \mathrm{W}, 2030 \mathrm{~m}\right.$ a.s.l. $)$. The temperature at $10 \mathrm{~m}$ was $-16.3^{\circ} \mathrm{C}$. We observed 2804 melt features, with a total thickness of $30.32 \mathrm{~m}$, in the $206.6 \mathrm{~m}$ core, corresponding to $16.4 \%$ by volume of the ice-equivalent core length. Horizontal distribution of melt features was examined by correlating melt-feature thicknesses in the two cores. The correlation coefficient was $0.71(n=514)$ for each melt feature in the two cores. It was maximum for data passed through 5 and 40 year low-pass filters. A significant relationship $(P=0.005, n=36)$ was obtained for the vertical distribution of melt features and the June temperature on the west coast of Greenland (Jakobshavn). Using this, June temperatures at Jakobshavn since 1550 were estimated. There are three periods (1685-1705, 1835-70 and 1933-45) during which mean June temperatures clearly decreased, when they were estimated to be $0.1^{\circ}, 0.4^{\circ}$ and $0.2^{\circ} \mathrm{C}$ lower than the average for the whole period (1550-1989). The first two "cold" periods have been identified in melt features of the Dye 3 and Devon Island ice cores and in a tree-ring profile from Yukon Territory, Canada. Melt-feature percentages in the Site J ice core have increased since about 1945, probably reflecting summer-temperature warming on the ice sheet.
\end{abstract}

\section{INTRODUCTION}

Glaciers and ice sheets can be classified into five zones based on the amount of surface snowmelting and accumulation (Benson, 1962; Paterson, 1981). The drysnow zone, the area where no summer melting occurs, is an ideal place for reconstructing past climatic and environmental conditions through ice-core analyses (Robin, 1983; Langway and others, 1985; Oeschger and Langway, 1989).

However, several reconstructions of past summer climates have been carried out using ice cores from below the dry-snow zone, in the percolation zone. These reconstructions assume that the amount of surface snowmelting in summer is related to the summer air temperature and/or solar radiation, with the amount of melting water being recorded as the volume of melt features (i.e. ice layers) in the snow. Melt-feature percentages (MFPs) in ice cores have been examined (Langway, 1967; Hibler and Langway, 1977; Koerner, 1977; Herron and others, 1981; Koerner and Fisher, 1981, 1990; Fisher and Koemer, 1983, 1994; Tarussov, 1992). These investigations have not systematically studied the horizontal distribution of melt features and the relationship between MFP and meteorological data. In Tarussov's (1992) study of the Austfonna ice core, MFP was converted to mean summer temperature (June, July and August) using the "Krenke-Khodakov equation". However, the validity of this equation for other regions has not been examined.

From May to June 1989, two continuous, mechanically drilled ice cores were recovered from Site J $\left(66^{\circ} 51.9^{\prime} \mathrm{N}, 46^{\circ} 15.9^{\prime} \mathrm{W}, 2030 \mathrm{~m}\right.$ a.s.l.; Fig. 1) on the west slope of southern Greenland by the Japanese Arctic 


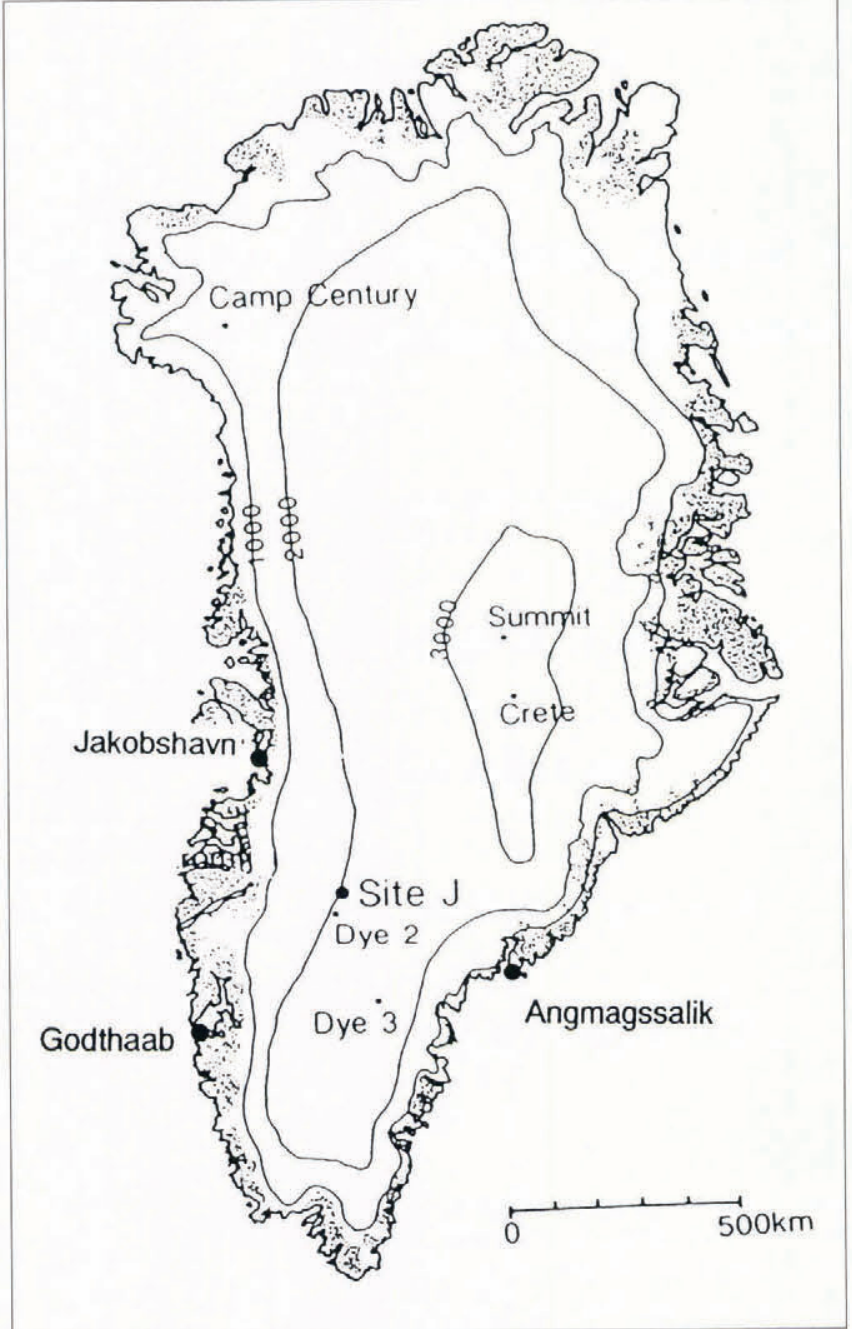

Fig. 1. Location of Site $\mathcal{f}\left(66^{\circ} 51^{\prime} \mathcal{N}, 46^{\circ} 15.9^{\prime} \mathrm{W}\right.$, 2030 ma.s.l.) on the west slope of South Greenland.

Glaciological Expedition (JAGE89) (Watanabe and Fujii, 1990). The ice cores were 206.6 and $101.8 \mathrm{~m}$ deep, respectively, and $1 \mathrm{~m}$ apart. The quality of both ice cores was excellent. The $10 \mathrm{~m}$ temperature was $-16.3^{\circ} \mathrm{C}$.

In this paper we focus on the horizontal and vertical distribution of melt features in the Site $J$ cores and evaluate relationships between the latter and meteorological data from the coast of Greenland.

\section{METHODS OF OBSERVATION AND ANALYSIS}

As soon as the ice cores were retrieved, they were stored in a storage and analytical room below the snow surface (Watanabe and Fujii, 1990) at a temperature that ranged from $-20^{\circ}$ to $-12^{\circ} \mathrm{C}$. Ice cores were set on a light table and subjected to detailed megascopic examination. Meltfeature shapes were recorded at full scale on a roll of graph paper, being clearly distinguishable with the transmitted light, as shown in Figure 2. The solid layers are melt features and the rest dry polar firn. Even after the pore close-off of air bubbles in the firn $(66 \mathrm{~m})$, the features can easily be distinguished by their relatively low bubble concentration.

MFP per $1 \mathrm{~m}$ length of core was calculated using Koerner's (1977) ice-percentage equation. This corrects for the effect of depth on firn compaction.

$$
\operatorname{MFP}(\%)=\frac{0.9 S_{\mathrm{i}}}{0.9 S_{\mathrm{i}}+\rho_{\mathrm{f}} S_{\mathrm{f}}} \times 100
$$

where $S_{\mathrm{i}}$ and $S_{\mathrm{f}}$ are the measured cross-sectional area of melt features and firn per $1 \mathrm{~m}$ length, respectively; 0.9 is the melt-feature density and $\rho_{\mathrm{f}}$ the firn density, both in $\mathrm{g} \mathrm{cm}^{-3}$. Below $90 \mathrm{~m}$ the firn becomes glacier ice, so at this point $0.9 \mathrm{~g} \mathrm{~cm}^{-3}$ is used for $\rho_{\mathrm{f}}$ in Equation (1).

Because MFP is an average for each $1 \mathrm{~m}$ core section (2.2 years on average), the annual MFP (AMFP) had to be calculated from it using a cubic spline curve (Ishida, 1982). A digital Chebyshev filter (Ashida and Saito, 1970) was used to examine the long-term trend of the AMFP. Cut-off frequencies (CF), half-power frequencies (HF) and maximum permissible ripple amplitudes (RA) could be justified individually in the filter. The filtering

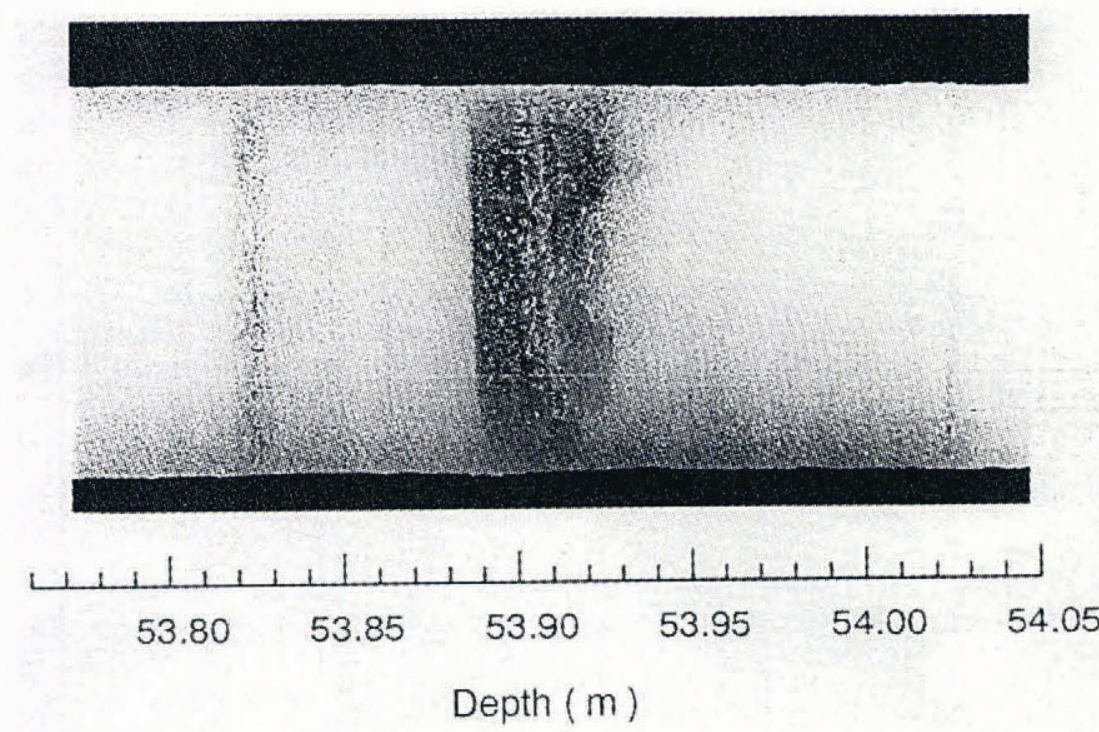

Fig. 2. Photograph of melt features in Site 7 ice cores. A $4 \mathrm{~cm}$ thick melt feature is observed in the center. The depth of the ice core is shown below the photograph. 
operation can be accomplished using the standard recursive method.

\section{MELT FEATURES}

\subsection{Thickness and interval distributions}

We observed 2804 melt features, with a total thickness of $30.32 \mathrm{~m}$, in the $206.6 \mathrm{~m}$ long core, corresponding to $16.4 \%$ by volume for an ice-equivalent core length of $184.8 \mathrm{~m}$. Their thickness distribution is summarised in Table $1.38 .4 \%$ of the melt features were $2 \mathrm{~mm}$ thick or less; $70.0 \%$ were $10 \mathrm{~mm}$ or less; and the overall average thickness was $10.8 \mathrm{~mm}$. The thickest feature was $210 \mathrm{~mm}$, observed at a depth of $1.40 \mathrm{~m}$. Ice-equivalent intervals between two adjacent melt features are summarised in Table 2. Interval calculations were made by correcting the density of firn observed between melt features. $36.6 \%$ of the intervals between adjacent melt features were within $0.02 \mathrm{~m}$, and $85.6 \%$ were within $0.1 \mathrm{~m}$. The mean interval was $0.058 \mathrm{~m}$ in ice-equivalent length.

In the $101.5 \mathrm{~m}$ core, 448 melt features, with a total thickness of $6.32 \mathrm{~m}$, were observed from the surface to $39.26 \mathrm{~m}$ depth; this amounted to $22.8 \%$ by volume for the ice-equivalent core length of $27.7 \mathrm{~m}$. Below $39.26 \mathrm{~m}$, no stratigraphic observations were made.

Table 1. Thickness distribution of all melt features from the surface to $206.6 \mathrm{~m}$ depth. The thickest melt feature was $210 \mathrm{~mm}$, observed at $1.40 \mathrm{~m}$ depth

\begin{tabular}{|c|c|c|}
\hline $\begin{array}{l}\text { Melt-features thickness } \\
\mathrm{mm}\end{array}$ & Appearances & Percentage \\
\hline $0<X \leq 10$ & 1962 & 70.0 \\
\hline $10<X \leq 20$ & 416 & 14.8 \\
\hline $20<X \leq 30$ & 174 & 6.2 \\
\hline $30<X \leq 40$ & 97 & 3.5 \\
\hline $40<X \leq 50$ & 44 & 1.6 \\
\hline $50<X \leq 60$ & 34 & 1.2 \\
\hline $60<X \leq 70$ & 29 & 1.0 \\
\hline $70<X \leq 80$ & 25 & 0.9 \\
\hline $80<X \leq 90$ & 7 & 0.2 \\
\hline $90<X \leq 100$ & 5 & 0.2 \\
\hline $100<X \leq 110$ & 2 & 0.1 \\
\hline $110<X \leq 120$ & 4 & 0.1 \\
\hline $120<X \leq 130$ & 1 & 0.0 \\
\hline $130<X \leq 140$ & 3 & 0.1 \\
\hline $140<X \leq 150$ & 0 & 0 \\
\hline $150<X \leq 160$ & 0 & 0 \\
\hline $160<X \leq 170$ & 0 & 0 \\
\hline $170<X \leq 180$ & 0 & 0 \\
\hline $180<X \leq 190$ & 0 & 0 \\
\hline $190<X \leq 200$ & 0 & 0 \\
\hline $200<X \leq 210$ & 1 & 0.0 \\
\hline$(0<X \leq 2)$ & (1078) & $(38.4)$ \\
\hline$(2<X \leq 4)$ & $(375)$ & $(13.4)$ \\
\hline$(4<X \leq 6)$ & $(210)$ & $(7.5)$ \\
\hline$(6<X \leq 8)$ & $(160)$ & $(5.7)$ \\
\hline$(8<X \leq 10)$ & $(139)$ & $(5.0)$ \\
\hline
\end{tabular}

Table 2. Melt feature intervals in ice-equivalent length from the surface to $206.6 \mathrm{~m}$ depth. The mean melt feature interval was $0.058 \mathrm{~m}$ in ice-equivalent length

Melt-features interval $\mathrm{m}$

Appearances Percenlage

\begin{tabular}{rrr}
\hline $0<X \leq 0.10$ & 2402 & 85.6 \\
$0.10<X \leq 0.20$ & 260 & 9.2 \\
$0.20<X \leq 0.30$ & 78 & 2.8 \\
$0.30<X \leq 0.40$ & 37 & 1.3 \\
$0.40<X \leq 0.50$ & 14 & 0.5 \\
$0.50<X \leq 0.60$ & 6 & 0.2 \\
$0.60<X \leq 0.70$ & 2 & 0.1 \\
$0.70<X \leq 0.80$ & 3 & 0.1 \\
$(0<X \leq 0.02)$ & $(942)$ & $(33.6)$ \\
$(0.02<X \leq 0.04)$ & $(641)$ & $(22.9)$ \\
$(0.04<X \leq 0.06)$ & $(408)$ & $(14.5)$ \\
$(0.06<X \leq 0.08)$ & $(245)$ & $(8.7)$ \\
$(0.08<X \leq 0.10)$ & $(166)$ & $(5.9)$ \\
\hline
\end{tabular}

\section{May 1989}

Horizontal Distance ( $\mathrm{cm}$ )

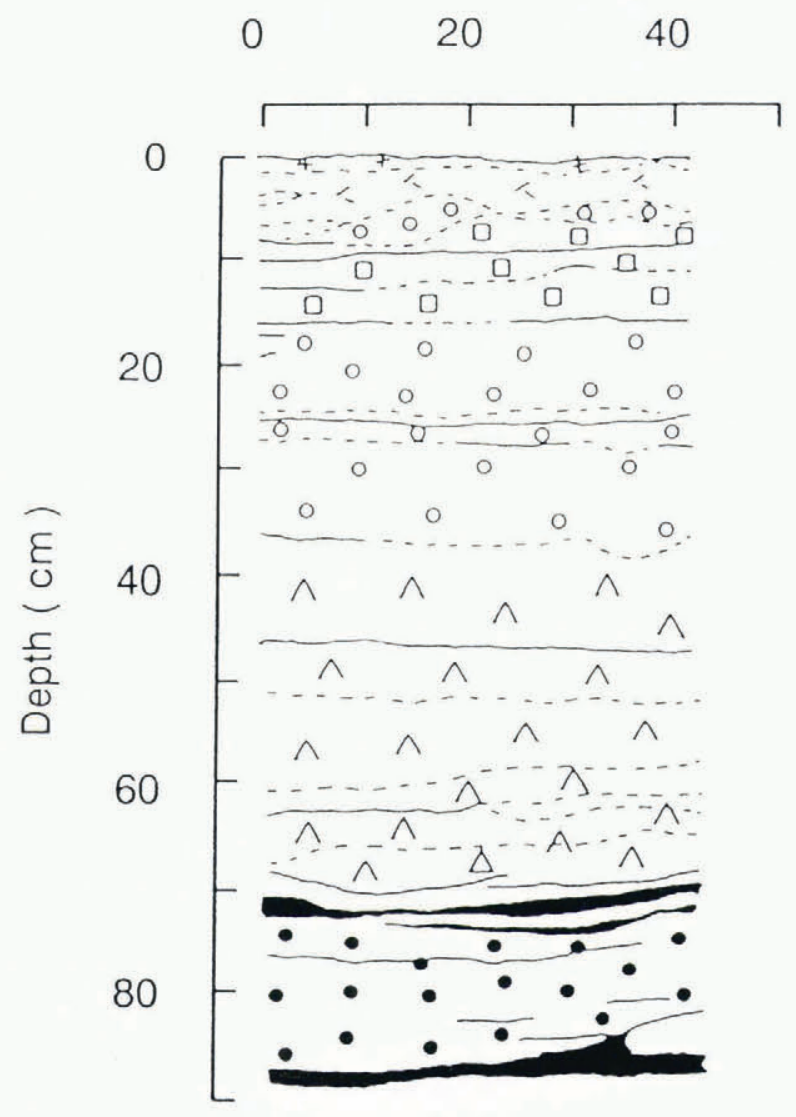

Fig. 3. A stratigraphic observation of a shallow pit at Site 7. Shaded areas show melt features, and symbols express snow qualities: $+, \Lambda, \square, \bigcirc, \Lambda$ and - express new snow, loose settled snow, small faceted snow, settled snow, depth hoar and granular snow, respectively (Japanese Society of Snow and Ice, 1970). 


\subsection{Horizontal distribution}

A stratigraphic section from a shallow pit at Site $\mathrm{J}$ is shown in Figure 3. Shaded areas are melt features, and the symbols express snow qualities according to the JSSI classification scheme (Japanese Society of Snow and Ice, 1970). It is obvious that the melt features are not horizontally uniform. Figure 4 shows their thickness in the two cores. The general trends in the profiles are quite similar. In the scatter diagram (Fig. 5), only features to a depth of $39.26 \mathrm{~m}$ in both cores are used. The correlation coefficient $(r)$ and the degree of freedom $(n)$ are 0.71 and
517, respectively, a $t$-distribution relation significant at the $P=0.001$ level. Equivalent melt features in the two cores were identified from their depth and thickness, depth deviations of $\pm 5 \mathrm{~cm}$ being allowed for the identification.

The 315 melt features identified in both cores are designated as B-type melt features: those found only in one are denoted as E-type and lie on either the $x$ or $y$ axis in Figure 5. The number and average thickness of the Band E-type melt features are summarised in Table 3.

Comparison of the annual melt thickness (AMT) in the cores gave a correlation coefficient of $0.75(P=0.001$,

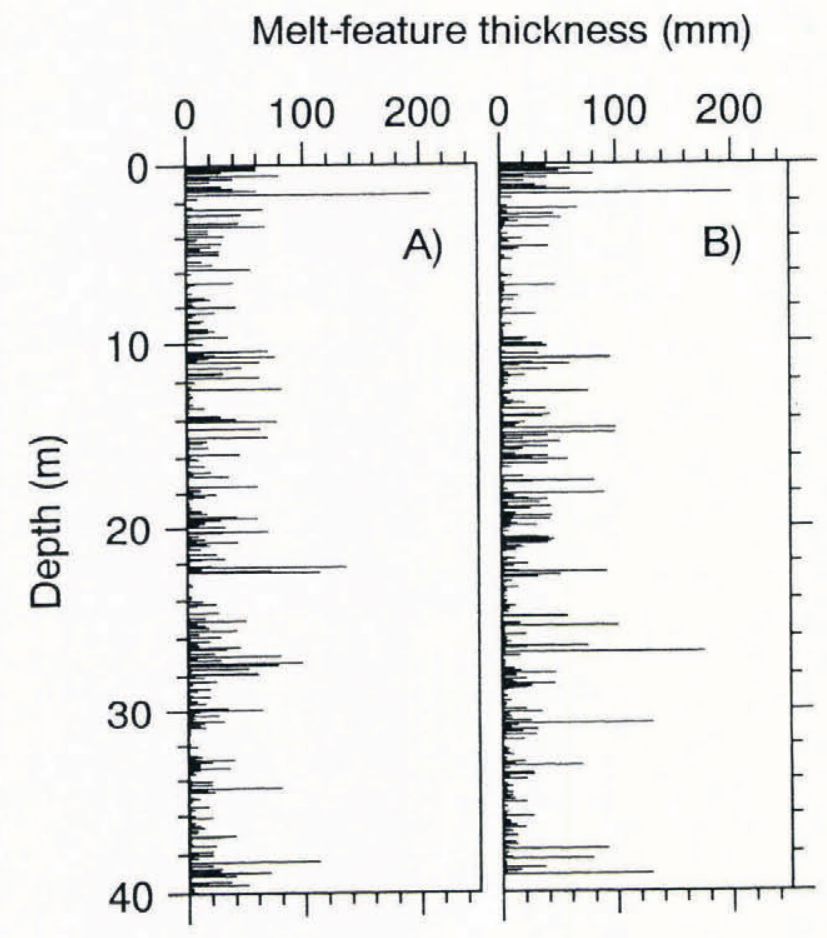

Fig. 4. Distributions of melt-feature thickness in two ice cores (A: $206.6 \mathrm{~m}$ core; $B: 101.5 \mathrm{~m}$ core) from the surface to $40 \mathrm{~m}$ depth.

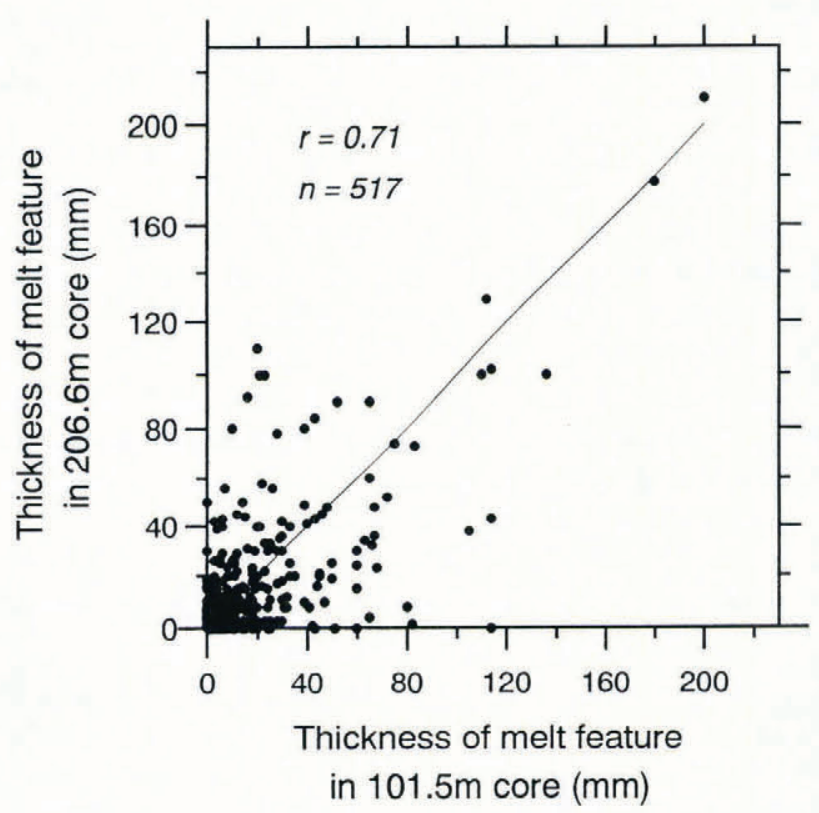

Fig. 5. The relation between thickness of the same melt features observed in the 206.6 and $101.6 \mathrm{~m}$ ice cores from the surface to a depth of $39.26 \mathrm{~m}$. Solid circles show measured thicknesses of melt features in 101.8 (x-axis) and $206.6 \mathrm{~m}$ ( $y$-axis) ice cores.

Table 3. Characteristics of B-and E-type melt features in the two ice cores from Site 7. Melt features which were observed in both ice cores are called B-lype melt features; melt features observed in only one ice core are called E-lype melt features

\begin{tabular}{lcc}
\hline Melt-feature characteristics & $206.6 \mathrm{~m}$ core & $101.5 \mathrm{~m}$ core \\
\hline $\begin{array}{l}\text { Depth range of stratigraphic observations } \\
\text { Total number of B-type melt features above } \\
\text { depth range }\end{array}$ & $0 \sim 39.26 \mathrm{~m}$ & $0 \sim 39.26 \mathrm{~m}$ \\
Total thickness of B-type melt features, and & $5.59 \mathrm{~m}$ & 345 \\
$\quad$ percentage for total depth range in ice & & $5.90 \mathrm{~m}$ \\
$\quad$ equivalent & $20.2 \%$ & $21.3 \%$ \\
$\begin{array}{l}\text { Mean B-type melt-feature thickness } \\
\text { Total number of E-type melt features above } \\
\text { depth range }\end{array}$ & $16.2 \mathrm{~mm}$ & $17.1 \mathrm{~mm}$ \\
Total thickness of E-type melt features, and & 71 & $0.61 \mathrm{~m}$ \\
$\quad$ percentage for total depth range in ice & & $0.42 \mathrm{~m}$ \\
equivalent & $2.2 \%$ & $1.5 \%$ \\
Mean E-type melt-feature thickness & $8.6 \mathrm{~mm}$ & $4.0 \mathrm{~mm}$ \\
\end{tabular}


$n=62$. Annual boundaries were determined by continuous $\delta^{18} \mathrm{O}$, dust and electrical-conductivity profiles (paper in preparation by Y. Fujii and others) and from stratigraphic records (mainly of the position of melt features). Figure 6 shows correlations between AMT in ice cores after smoothing by an $m$ year low-pass filter. The initial maximum value is found at $m=5 \quad(r=0.80$, $P=0.001, n=59)$ and the minimum at $m=25$ $(r=0.09, n=46)$ before a rise to the highest value at $m=40(r=0.94, P=0.001, n=27)$. Snow accumulation at the 5 and 40 year periods was about 4 and $15 \mathrm{~m}$, respectively.

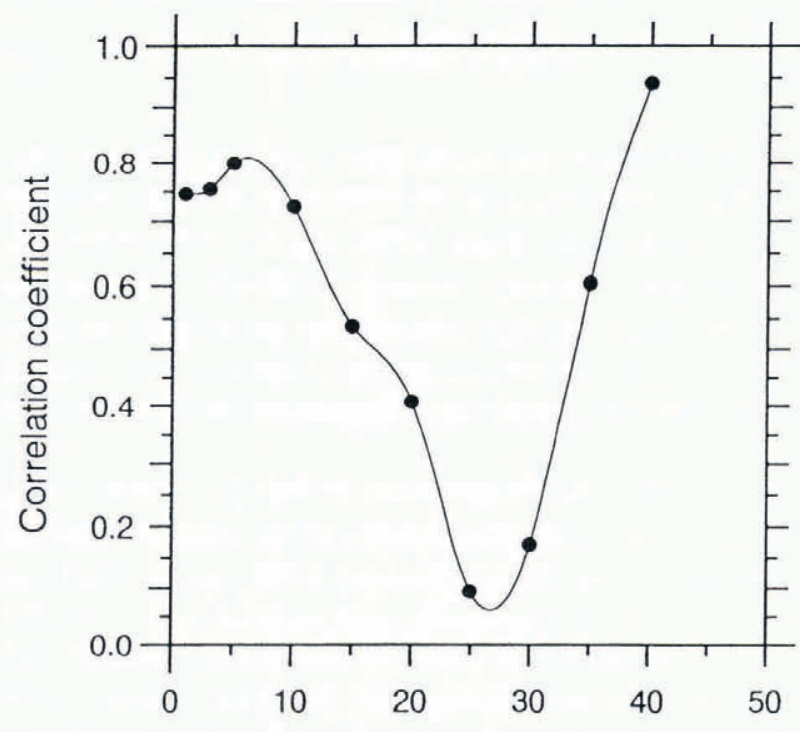

Period (years) in low-pass filter

Fig. 6. Correlation coefficients between annual melt thicknesses (AMTs) in the two ice cores after an myear low-pass filter. The xaxis is $m$.

\subsection{Vertical distribution}

A vertical profile of MFP (thin line) in the $206.6 \mathrm{~m}$ core is shown in Figure 7, with estimated ages. The thick line is the MFP profile after a 60 year low-pass filter $\left(\mathrm{CF}=0.01499\right.$ year $^{-1}, \mathrm{HF}=0.01666$ year $^{-1}, \mathrm{RA}=$ $0.5 \mathrm{~dB})$. This filter was selected because the short-term air-temperature oscillations between West and East Greenland are not in phase, and differences occur even in the 30 year smoothed curves (Dansgaard and others, 1977). Ice below $103 \mathrm{~m}$ was dated by electrical conductivity which detected volcanic layers (paper in preparation by F. Nishio and others). The time-scale probably deviates less than \pm 5 year between the surface and $103 \mathrm{~m}$ and by \pm 10 year from 103 to $206 \mathrm{~m}$ depth. Shoji and others (1991) have published preliminary results of the core dating.

There are two low-MFP periods in the profile, 16851705 and 1835-70, including remarkably low MFP from 1835 to 1842 . These characteristics of the profile suggest past variations of summer temperature and/or solar radiation at Site J.

\section{DISCUSSION}

\subsection{Relation between melt-feature thickness and summer temperature}

Simple relations between annual melt thickness (AMT) and monthly mean summer temperatures on the coast of Greenland were examined. Summer temperatures were selected because of their long period and uniform quality. Three meteorological stations (Jakobshavn, Godthaab and Angmagssalik) close to Site J were used (Fig. 1). Summer temperature data came from World Weather Records (1927, 1934, 1947, 1959, 1968, 1981).

The correlation coefficients between AMT and monthly summer temperatures are summarised in Table 4. AMT is well correlated with June temperatures in West

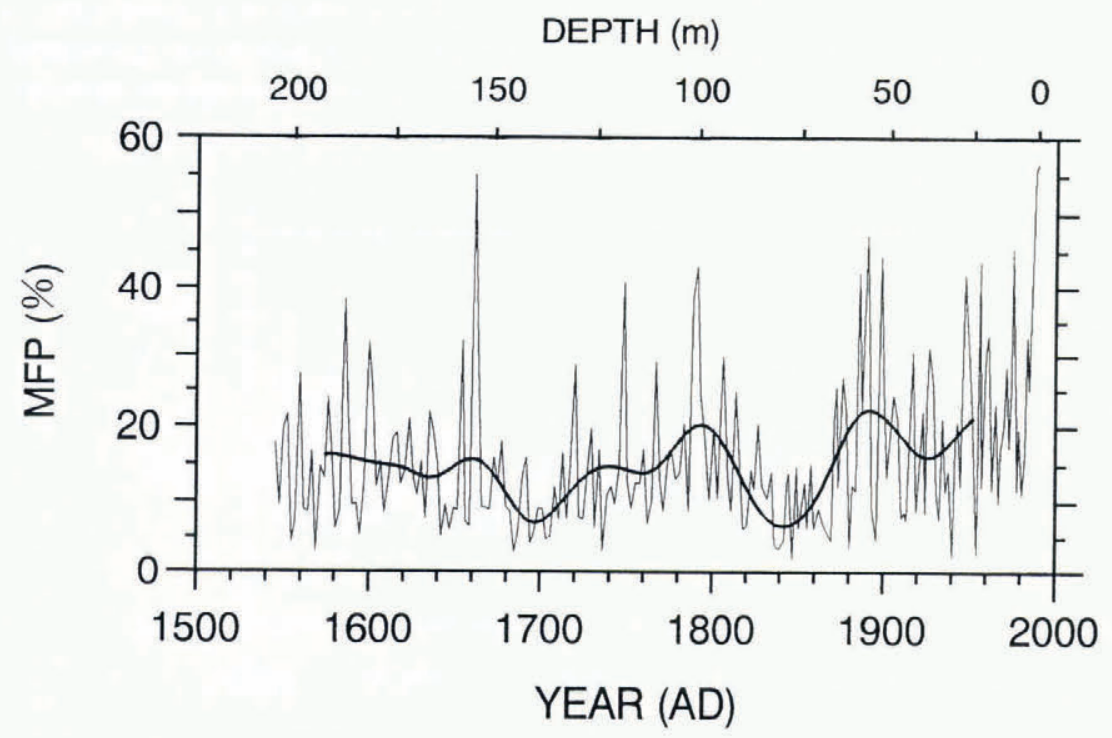

Fig. 7. Melt-feature percentage (MFP) in the Site 7 ice core. The thin line shows MFP for each $1 \mathrm{~m}$ interval (2.2 years on average). The thicker line shows the MFP after a 60 year low-pass filter. 
Table 4. Correlation coefficients between annual melt thickness (AMT) and summer temperatures on the Greenland coast (AD 1926-63; degree of freedom is 36). Significance levels are shown by the number of asterisks, $0.10\left(^{*}\right), 0.025\left(^{* *}\right)$ and $0.005\left(^{* * *}\right)$

\begin{tabular}{lllll}
\hline & fune & Fuly & August & \begin{tabular}{c} 
fune $+\begin{array}{c}\text { fuly }+ \\
\text { August }\end{array}$ \\
\hline Jakobshavn
\end{tabular} \\
Godthaab & $0.49^{* * *}$ & 0.20 & 0.21 & $0.42^{* *}$ \\
Angmagssalik & $0.41^{* *}$ & 0.16 & 0.13 & $0.30^{*}$ \\
& 0.17 & 0.06 & 0.14 & 0.10 \\
\hline
\end{tabular}

Greenland (Jakobshavn and Godthaab) and poorly correlated with those in East Greenland (Angmagssalik). Figure 8 shows the "best relation" between AMT

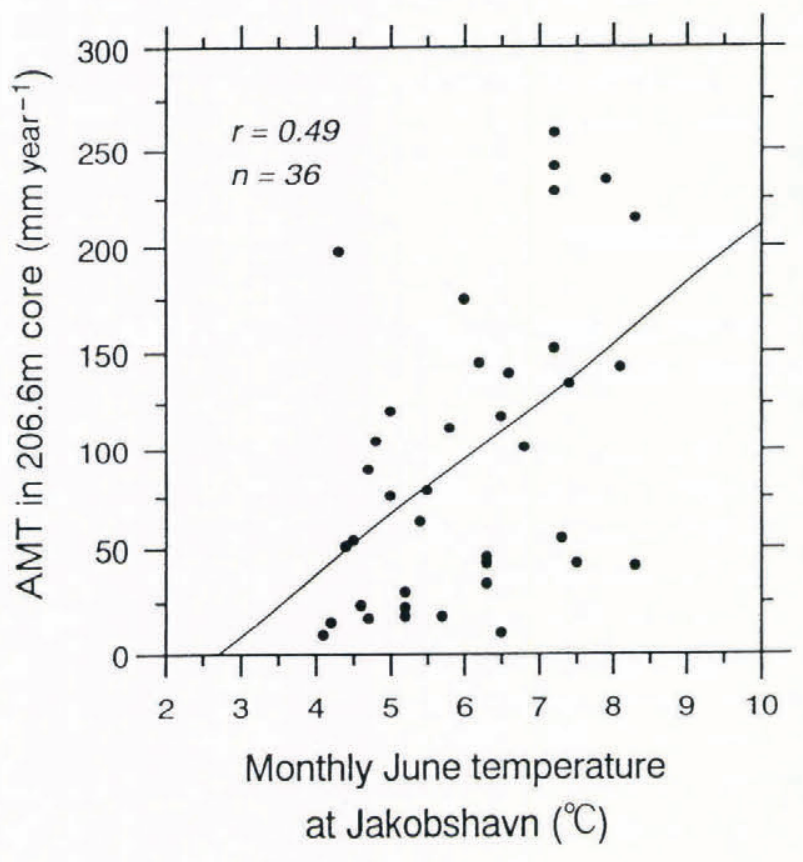

Fig. 8. The relation between monthly fune temperatures at Jakobshavn, West Greenland, and annual melt thickness (AMT) in the Site 7 ice core (AD 1926-63). The correlation coefficient and degree of freedom are 0.49 and 35 , respectively. and monthly mean June temperatures at Jakobshavn from 1926 to 1963 (significant at $P=0.005, n=36$ ). Equation (2) is the linear regression obtained in Figure 8.

$$
\mathrm{AMT}=28.87 T-77
$$

where AMT and $T$ are in mm year $^{-1}$ and ${ }^{\circ} \mathrm{C}$, respectively. The 1963 horizon was determined by the tritium concentration peak (Fujii, 1991, fig. 1). The relatively short reference period (38 years; 1926-63) was due to difficulties in identifying annual layer boundaries reliably because the melt features partly influence the original $\delta^{18} \mathrm{O}$ oscillations (paper in preparation by Y. Fujii and others).

The mean June temperature at Site $\mathrm{J}$ is about $-5^{\circ} \mathrm{C}$, according to the map of monthly surface temperatures for the Greenland ice sheet (Ohmura, 1987, fig. 9). Surfacesnow layers at Site J probably start melting in this month, and melt features will form in the snow. Because the surface was cooled during the previous winter, melt features are effectively produced from meltwater, hence the "best relation" between AMT and the June monthly temperature.

\subsection{Past summer climate reconstruction from the MFP profile}

Figure 9 shows estimated deviations of June monthly temperatures for Jakobshavn calculated from Equation (2). The apparent temperature decrease along the core

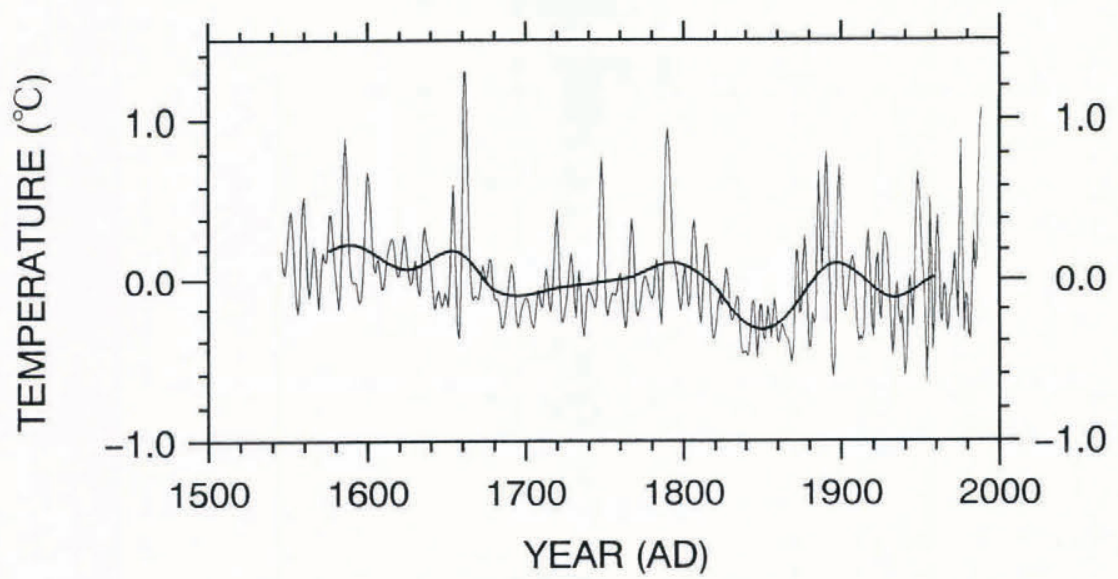

Fig. 9. Reconstructed June temperatures at Jakobshavn, West Greenland. Deviations of temperatures from the whole period (AD 1547-1989) are shown. 
depth, caused by ice-sheet flow, was corrected using a lapse rate of $0.75^{\circ} \mathrm{C}$ per $100 \mathrm{~m}$, an ice velocity of 38.4 mear $^{-1}$ and an average ice-sheet slope of $0.20^{\circ}$. The June lapse rate on the west coast of Greenland (Ohmura, 1987) was used. The ice-flow velocity was taken from the "Western Cluster" (Drew and Whillans, 1984) because it is positioned at nearly the same distance from the ice divide as Site $\mathrm{J}$ (about $180 \mathrm{~km}$ ). The average slope was estimated from surface topographic data of the Greenland ice sheet (Bindschadler and others, 1989). Four grid-point positions $(347,220 ; 349,220 ; 347,221$; 349,221 ) around Site $J$ were selected and the average slope to a point $17 \mathrm{~km}$ upstream calculated (the ice at Site $\mathrm{J}$ at $206 \mathrm{~m}$ depth was probably deposited in 1550). Using this method, corrections were $+0.21^{\circ} \mathrm{C}$ at $100 \mathrm{~m}$ depth and $+0.45^{\circ} \mathrm{C}$ at $206 \mathrm{~m}$.

Because short-term oscillations of air temperature (<30year) are not in phase between West and East Greenland (Dansgaard and others, 1977), only signals long enough to be significant are discussed. It is obvious that there are three periods when summer temperatures decreased: 1685-1705, 1835-70 and 1933-45. Average summer temperatures during these periods are estimated to be $0.1^{\circ}, 0.4^{\circ}$ and $0.2^{\circ} \mathrm{C}$ lower, respectively, than the average for the whole period (1546-1989). From 1835 to 1842, estimated as the coldest summer seasons during the last 450 years, summer temperatures were $0.5^{\circ} \mathrm{C}$ lower than the average.

Figure 10 gives the spectral distribution obtained from

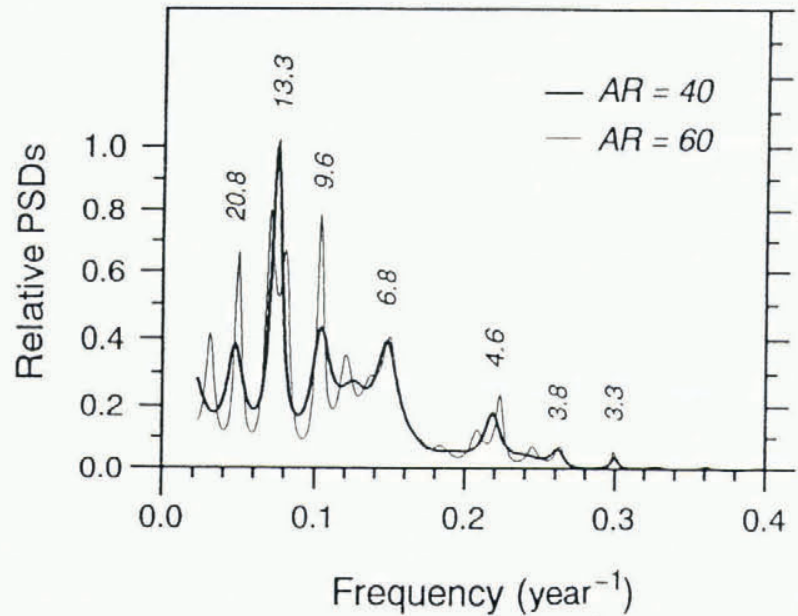

Fig. 10. Power spectral densities (PSDs) normalized on the largest peak $(13.3$ year in $A R=40)$, obtained from MEM using Burg algorithm. Auto-regressive (AR) orders are 40 and 60 . The periods are given in years for each individual peak for $A R=40$. The peaks present at $A R$ of 60 are 32.3, 20.0, 14.3, 12.5, 9.7, 8.3, 6.7, 4.5, $4.1,3.8$ and 3.3 .

the Burg MEM (maximum entropy method) for autoregressive (AR) orders 40 and 60. The MEM time-series model equation is a linear auto-regression one, in which each value is a weighted sum of $M$ past data points

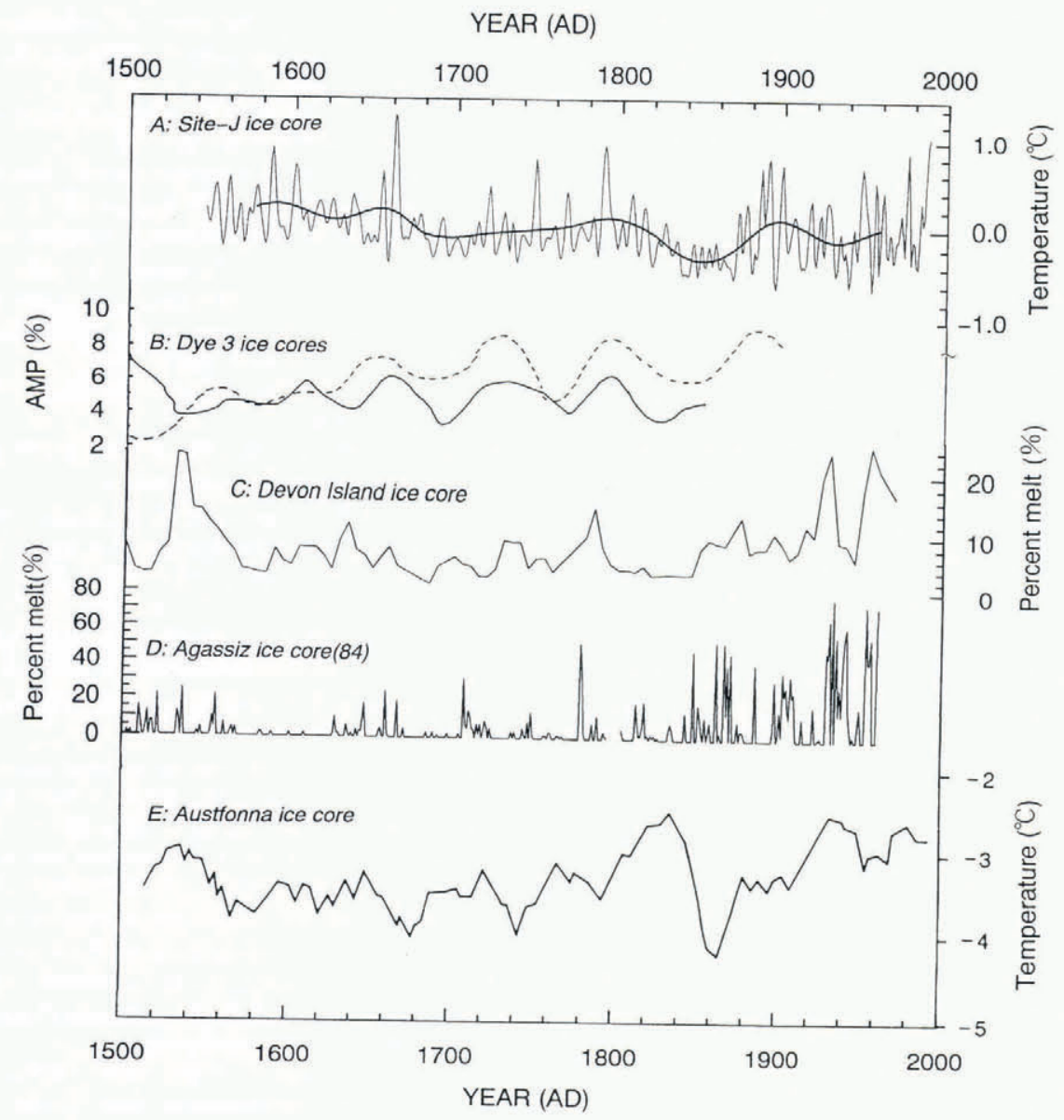

Fig. 11. Comparison of estimated June temperature deviations from Site $\mathcal{J}(A)$ with previous studies of melt-feature profiles $(B, C, D$ and $E)$. 
together with random noise, where $M$ is the $A R$ order. The latter was selected at the minimum final prediction error, according to Ulrych's (1974) suggestion. Power spectral densities are normalized on the largest peak obtained at the 13.3 year cycle $(\mathrm{AR}=40)$. This peak, and the split peaks at the 14.3 and 12.2 year cycles $(\mathrm{AR}=60)$, are well identified in Figure 10 .

\subsection{Comparison with previous studies}

In Figure 11, the estimated June temperature deviations (A) are compared with previous studies of melt-feature profiles in ice cores (B, C, D and E). The profiles of the Dye 3 (B) ice core are taken from Herron and Langway (1981). The dashed line is from the Dye 3 core drilled in 1971 and the solid line from that drilled in 1979. The Devon Island (C) and Agassiz Ice Cap (D) core profiles are from Fisher and Koerner (1994). That for Austfonna (E) comes from Tarussov (1992).

A common low-MFP (cold-summer) period (about 1830-50) can be seen clearly in the A, B, C and D profiles but seems to have been delayed by about 20 years in profile E. Another unusual "cold" period (1680-1700) that can be seen in the first four profiles is delayed about 10 years in profile $\mathrm{E}$.

The same unusual "cold periods" around AD 1690 and 1840 can be observed in the tree-ring profile at TT-HH from Yukon Territory, Canada (Jacoby and Cook, 1984). Jacoby and Cook (1984) suggested that the profile reflects mean June July temperatures and total degree days above $10^{\circ} \mathrm{C}$ for June plus July, which seems to play an important role in MFP. In- and out-of-phase characteristics of these profiles suggest spatial and temporal variability of mean summer temperatures during the last 450 years.

\section{ACKNOWLEDGEMENTS}

The authors would like to express their sincere gratitude to GRIP members at the GOC field headquarters in Sondre Stromfjord who supported our field activities through daily radio communications. They also wish to express their thanks to all members of the Japanese Arctic Glaciological Expedition 1989, especially to the ice-coring technicians, Y. Tanaka and M. Miyahara. This research was supported by a Grant-in-Aid for International Scientific Research from the Japanese Ministry of Education, Science and Culture (principal investigator Professor O. Watanabe).

\section{REFERENCES}

Ashida, Y. and M. Saito. 1970. Design of digital Chebyshev filters. Butsuri-Tanko, 23 (1), 6-19. In Japanese with English abstract.

Benson, C. S. 1962. Stratigraphic studies in the snow and firn of the Greenland ice sheet. SIPRE Res. Rep. 70.

Bindschadler, R. A., H.J. Zwally, J. A. Major and A. C. Brenner. 1989. Surface topography of the Greenland ice sheet from satellite radar altimetry.
Washington, DC, National Aeronautics and Space Administration. (NASA SP-503.)

Dansgaard, W., N. Gundestrup, C. Hammer, S. J. Johnsen and N. Reeh. 1977. The climatic significance of stable isotopes in polar glaciers. In Dunbar, M.J., ed. Polar oceans. Calgary, Arctic Institute of North America, 585-588.

Drew, A.R. and I.M. Whillans. 1984. Measurement of surface deformation of the Greenland ice sheet by satellite tracking. Ann. Glaciol., 5, 51-55.

Fisher, D. A. and R. M. Koemer. 1983. Ice-core study: a climatic link between the past, present and future. Syllogeus 49, 50-69. Climatic Change in Canada 3. .

Fisher, D. A. and R. M. Koerner. 1994. Signal and noise in four ice-core records from the Agassiz Ice Cap, Ellesmere Island, Canada: detail of the last millennium for stable isotopes, melt and solid conductivity. Holocene, 4(2), 113-120.

Fujii, Y. 1991. Correspondence. Reply to "Comments on: "6000-year climate records in an ice core from the Hoghetta ice dome in northern Spitsbergen"”. J. Glaciol., 37(125), 186-188.

Herron, M. M., S. L. Herron and C. C. Langway, Jr. 1981. Climatic signal of ice melt features in southern Greenland. Nature, 293 (5831). 389-391.

Hibler, W. D., III and C. C. Langway, Jr. 1977. Ice core stratigraphy as a climatic indicator. In Dunbar, M.J., ed. Polar oceans. Calgary, Arctic Institute of North America, 589601.

Ishida, T. 1982. BASIC programs. I. Low Temp. Sci. Dala Rep., Ser. A 41 , 83-90.

Jacoby, G. C. and E. R. Cook. 1981. Past temperature variations inferred from a 400-year tree-ring chronology from Yukon Territory, Canada. Arct. Alp. Res., 13 (4), 409418.

Japanese Society of Snow and Ice. 1970. Classification of snow cover. Seppyo no Kenkyu, 4, 31-49. In Japanese.

Koerner, R.M. 1977. Devon Island ice cap: core stratigraphy and paleoclimate. Science, 196 (4285), 15-18.

Koerner, R. M. and D. A. Fisher. 1981. Studying climatic change from Canadian high Arctic ice cores. Syllogeus 33, 195-218.

Koerner, R. M. and D. A. Fisher. 1990. A record of Holocene summer climate from a Canadian high-Arctic ice core. Nature, 343(6259), $630-631$.

Krenke, A. N. 1982. Massoobmen v lednikovykh sistemakh na territorii SSSR Mass exchange in glacier system of the U.S.S.R.]. Leningrad, Gidrometeoizdat.

Langway, C. C., Jr. 1967. Stratigraphic analysis of a deep ice core from Greenland. CRREL Res. Rep. 77

Langway, C. C., Jr, H. Oeschger and W. Dansgaard, eds. 1985. Greenland ice core: geophysics, geochemistry, and the environment. Washington, DC, American Geophysical Union. Geophysical Monograph 33.

Oeschger, H. and C. C. Langway, Jr. 1989. The environmental record in glaciers and ice sheets. Chichester, etc. John Wiley and Sons.

Ohmura, A. 1987. New temperature distribution maps for Greenland. Z. Gletscherkd. Glazialgeol., 23 (1), 1-45.

Paterson, W. S. B. 1981. The physics of glaciers. Second edition. Oxford, etc., Pergamon Press.

Robin, G. de Q.ed. 1983. The climatic record in polar ice sheels. Cambridge, etc.. Cambridge University Press.

Shoji, H., H. B. Clausen and T. Kameda. 1991. Accumulation rate at Site-J and Dye-2, Greenland. Bull. Glacier Res. 9, 85-88.

Smithsonian Institution. 1927, 1934, 1947. World weather records, Smithson. Misc. Collect., 79, 90, 105.

Tarussov, A. 1992. The Arctic from Svalbard to Severnaya Zemblya: climatic reconstructions from ice cores. In Bradley, R.S. and P. D. Jones, eds. Climate since A.D. 1500. London and New York, Routledge, 505-516.

Ulrych, T.J. 1972. Maximum entropy power spectrum of truncated sinusoids. 7. Geophys. Res., 77 8), 1396-1400.

United States. Department of Commerce. 1959. World weather records. Washington, DC, U.S. Department of Commerce. Weather Bureau.

United States. Department of Commerce. 1968. World wealher records, Washington, DC, L.S. Department of Commerce. Environmental Science Service Administration. Environmental Data Service.

United States. Department of Commerce. 1981. World weather records. Washington, DC, U.S. Department of Commerce. National Oceanic and Atmospheric Administration.

Watanabe, O. and Y. Fujii. 1990. Outline of the Japanese Arctic Glaciological Expedition in 1989 (JAGE 1989). Bull. Glacier Res. 8, $103-106$ 